\title{
A New Acetylated Flavonoid Glycoside from Myrsine africana $\mathrm{L}$
}

\author{
Yanping Zou, Changheng Tan, ${ }^{\dagger}$ and Dayuan Zhu ${ }^{\dagger *^{*}}$ \\ Department of Cereal and Food Sciences, North Dakota State Lniversity, Fargo, ND 58105 \\ - State Kev Laboratorv of Drug Research. Institute of Materia Medica, Shanghai Institutes for Biological Sciences, \\ Chinese Academ of Sciences, Shanghai, 201203, P. R. China. E-mail: drahramailshonc.ac.ch \\ Received April 6, 2009, Accepted Hav 19, 2009
}

Key Wonds: Mrrsine africana L., Flavonoid. Mearnsetin 3-(2",4"-diacetylrhanmoside)

Mrsine africana L is a small shnig plant of the Myrsinaceae family. and distributed in Africa. Europe and the Shanxi. Guangxi. Gansu. Xizang provinces of China. Mrrsine african L. has been used traditionally for the treatment of diarrhea. rheumatism. toothache. pulmonary tuberculosis. and relieving hemorrhage. ${ }^{1}$ Previous phytochemical investigations on $M$. africana $\mathrm{L}$. have resulted in the isolation of flavonoids, ${ }^{2.3 .4}$ benzoquinones. ${ }^{5}$ and triterpenoids. Our chemical constituents study on the stems of $M$. africana $\mathrm{L}$. led to the isolation of ten flavonoid compounds, including a new ones. mearnsetin 3-(2". 4"-diacetylrhamnoside) (1), along with nine known flavonoids 2-10 (Figure 1)

The dried and powdered stems of $M$. africana L. were extracted with $95 \% \mathrm{EtOH}$. After concentration under reduced pressure. the extract was suspended in $\mathrm{H}_{2} \mathrm{O}$ and partitioned successively with petroleum ether, $\mathrm{CHCl}_{3}$. EtOAc. and $\mathrm{BuOH}$. The EtOAc-soluble fraction was separated by repeated chromatographic procedures to give a new acetylated flavonoid glycoside 1. along with seven known flavonoids 2. 3. and 5-9. Repeated column chromatography of the $\mathrm{BuOH}$-soluble fraction resulted in the isolation of two known flavonoids 4 and 10. Depending on chromatographic and spectroscopic analysis, 2-10 were identified as quercitrin (2), myricitrin (3). ${ }^{9}$ mearnsitrin $(4) .{ }^{9}$ mỵ ricetin-3-O-(4"-O-acetyl)-a-L-rhamnopy ranoside (5). ${ }^{10}$ meansetin-3-O-(4"-O-acetyl)-a-L-rhamnopy ranoside $(6) .^{9}(-)$-epicatechin $(7) .^{\mathrm{Jl}}(-)$-epigallocatechin
$(8){ }^{12}{ }^{4}(-)$-epigallocatechin-3-O-gallate $(9),{ }^{13}$ and $3^{\prime} .5^{\prime}-\mathrm{di}-C-\beta$ glucopyranosyl phloretin $(\mathbf{1 0})$. $^{17}$

Compound 1. obtained as yellow amorphous powder. had the molecular formula $\mathrm{C}_{26} \mathrm{H}_{26} \mathrm{O}_{14}$ as deduced by the $\mathrm{HR}$ ESI-MS ( $m / z: 585.1191,[\mathrm{M}+\mathrm{Na}]^{+}$. calcd. 585.1220 for $\mathrm{C}_{26} \mathrm{H}_{26} \mathrm{O}_{14} \mathrm{Na}^{-}$). The IR bands exhibited the present of hydro$\mathrm{xyl}$ groups $\left(3+1 \mathrm{~cm}^{-1}\right)$, carbonyl group $\left(1731 \mathrm{~cm}^{-1}\right)$. and aromatic rings ( 1612 and $1442 \mathrm{~cm}^{-1}$ ). Acidic hydrolysis of 1 gave L-rlanmose as the sugar moiety. The ${ }^{l} \mathrm{H}-\mathrm{NMR}$ spectrum (Table 1) of 1 showed signals for a meamsetin unit. ${ }^{15}$ an $\alpha$ rhamnose fragment, and two acetyl groups $\left(\delta_{\mathrm{H}} 2.09\right.$ and 2.04 , each $3 \mathrm{H}$. s). The former aglycone unit was characterized by a pair of meta-coupled protons at $\delta_{\mathrm{H}} 6.45$ and 6.39 (each $1 \mathrm{H}$, d. $J=2.1 \mathrm{~Hz})$. two aromatic protons at $\delta_{\mathrm{H}} 6.87(2 \mathrm{H}, \mathrm{s})$, and a methoxyl $\left(\delta_{\mathrm{H}} 3.88,3 \mathrm{H}, \mathrm{s}\right)$. The sugar moiety comprised an anomeric proton at $\delta_{\mathrm{H}} 5.55$ (1H. d. $\left.J=1.8 \mathrm{~Hz}\right)$, one methyl $\left(\delta_{\mathrm{H}}\right.$ $0.79 .3 \mathrm{H}, \mathrm{d} J=6.0 \mathrm{~Hz})$, and four methines at $\delta_{\mathrm{H}} 5.47(\mathrm{lH}$, dd. $J=3.3 .1 .8 \mathrm{~Hz}), 4.76(1 \mathrm{H} . \mathrm{t} . J=9.9 \mathrm{~Hz}) .4 .10(1 \mathrm{H} . \mathrm{dd}, J=9.4$. $3.6 \mathrm{~Hz})$, and $3.28(\mathrm{lH}$. dd. $J=9.9 .6 .0 \mathrm{~Hz})$. The ${ }^{13} \mathrm{C}-\mathrm{NMR}$ and DEPT spectral (Table I) displayed 26 carbon signals. including a flavone skeleton ( $1+$ olefinic and one conjugated carbonyl carbons), two acetyls ( $\delta_{c}-172.9,172.2,21.4$. and 21.3 ). a methoxyl $\left(\delta_{c}, 56.9\right)$, and one rhanmose signals $(99.4,73.4$, $68.9 .75 .5,69.9,18.1)$. The above evidences suggested 1 to be diacetylated mearnsetin rhannoside. The linkage position of the rhamnosyloxyl and the two acetyls were deternined on

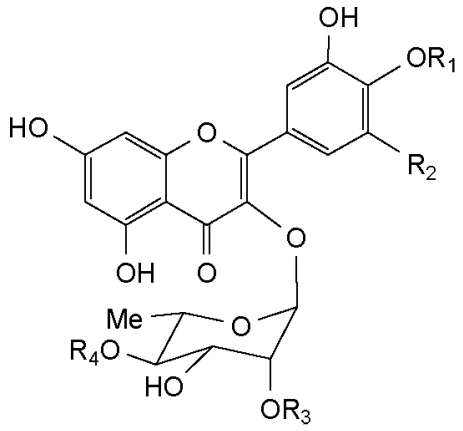

$1 \mathrm{R}_{1}=\mathrm{CH}_{3}, \mathrm{R}_{2}=\mathrm{OH}, \mathrm{R}_{3}=\mathrm{R}_{4}=\mathrm{COCH}_{3}$

$2 \mathrm{R}_{1}=\mathrm{R}_{2}=\mathrm{R}_{3}=\mathrm{R}_{4}=\mathrm{H}$

$3 \mathrm{R}_{1}=\mathrm{R}_{3}=\mathrm{R}_{4}=\mathrm{H}_{1} \mathrm{R}_{2}=\mathrm{OH}$

$4 \mathrm{R}_{1}=\mathrm{CH}_{3}, \mathrm{R}_{2}=\mathrm{OH}, \mathrm{R}_{3}=\mathrm{R}_{4}=\mathrm{H}$

$5 \mathrm{R}_{1}=\mathrm{R}_{3}=\mathrm{H}_{1} \mathrm{R}_{2}=\mathrm{OH}, \mathrm{R}_{4}=\mathrm{COCH}_{3}$

$6 \mathrm{R}_{1}=\mathrm{CH}_{3}, \mathrm{R}_{2}=\mathrm{OH}, \mathrm{R}_{3}=\mathrm{H}_{1} \mathrm{R}_{4}=\mathrm{COCH}_{3}$<smiles>[R7]c1cc([C@@H]2Oc3cc(O)cc(O)c3C[C@H]2[R20])cc(O)c1O</smiles>

$7 \mathrm{R}_{1}=\mathrm{R}_{2}=\mathrm{H}$

$8 \mathrm{R}_{1}=\mathrm{OH}, \mathrm{R}_{2}=\mathrm{H}$

$9 \mathrm{R}_{1}=\mathrm{OH}, \mathrm{R}_{2}=$ galloyl

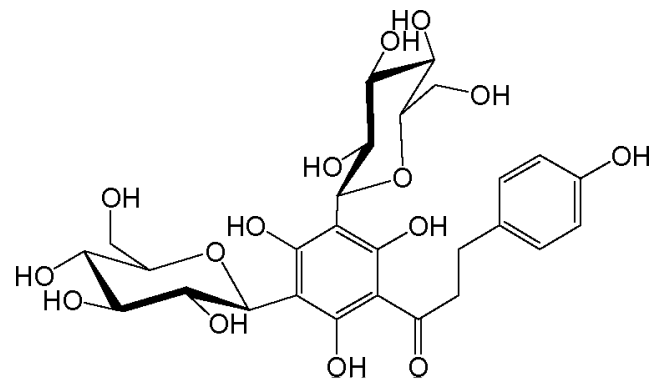

10

Figure 1. Structures of flavonoids isolated from M. africana L. 
Table 1. ${ }^{1} \mathrm{H}$ - and ${ }^{13} \mathrm{C}-\mathrm{NMR}$ spectral data of 1 ( 400 and $100 \mathrm{MHz}, J$ in $\mathrm{Hz}, \mathrm{CD}_{3} \mathrm{OD}$ )

\begin{tabular}{|c|c|c|c|c|c|}
\hline position & $\delta_{\mathrm{H}}$ & $\delta_{\mathrm{C}}$ & position & $\delta_{\mathrm{H}}$ & $\delta_{C}$ \\
\hline 2 & & 160.8 & $I^{\prime \prime}$ & $5.55(\mathrm{~d}, 1.8)$ & 99.4 \\
\hline 3 & & 137.1 & $2^{\prime 1}$ & $5.47(\mathrm{dd}, 3.3,1.8)$ & 73.4 \\
\hline 4 & & 175.6 & $3^{* 1}$ & $4.10(\mathrm{dd}, 9.4,3.6)$ & 68.9 \\
\hline 5 & & 163.1 & $4^{\prime \prime}$ & $4.76(\mathrm{t}, 9.9)$ & 75.5 \\
\hline 6 & $6.39(\mathrm{~d}, 2.1)$ & 97.7 & $5^{\prime \prime}$ & $3.28(\mathrm{dd}, 9.9,6.0)$ & 69.9 \\
\hline 7 & & 165.5 & $6^{\prime \prime}$ & $0.79(\mathrm{~d}, 6.0)$ & 18.1 \\
\hline 8 & $6.45(\mathrm{~d}, 2.1)$ & 96.6 & $2^{\prime \prime}-\mathrm{OCOCH}_{3}$ & & 172.2 \\
\hline 9 & & 157.9 & $2^{\prime \prime}-\mathrm{OCOCH}_{3}$ & $2.09(\mathrm{~s})$ & 21.3 \\
\hline 10 & & 109.1 & $4^{\prime \prime}-\mathrm{OCOCH}_{3}$ & & 172.9 \\
\hline $1^{\prime}$ & & 122.6 & $4 "-\mathrm{OC} O \mathrm{OCH}_{3}$ & $2.04(\mathrm{~s})$ & 21.4 \\
\hline $2^{\prime}$ & $6.87(\mathrm{~s})$ & 109.7 & & & \\
\hline$\hat{3}^{\prime}$ & & 147.5 & & & \\
\hline $4^{\prime}$ & & 138.0 & & & \\
\hline $5^{\prime}$ & & 147.5 & & & \\
\hline $6^{\prime}$ & $6.87(\mathrm{~s})$ & 109.7 & & & \\
\hline 4'-OMe & $3.88(\mathrm{~s})$ & 56.9 & & & \\
\hline
\end{tabular}

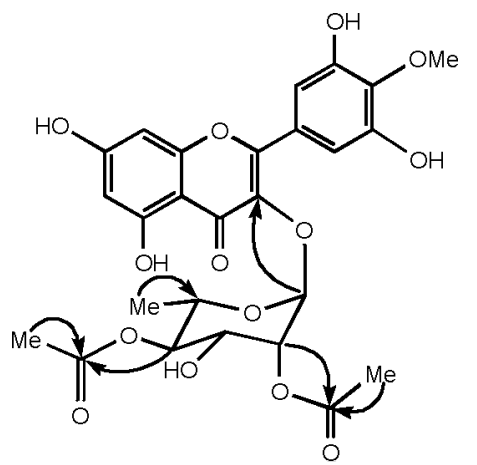

Figure 2. Key HMBC correlations of $\mathbf{1}(\mathrm{H} \rightarrow \mathrm{C})$.

C-3. C-2" and C-4" on the basis of HMBC cross-peaks of $\dot{\delta}_{\mathrm{H}}$ $5.55(\mathrm{H}-1 ") / \delta_{C} 137.1(\mathrm{C}-3), \delta_{\mathrm{H}} 5.47\left(\mathrm{H}-2^{\prime \prime}\right) / \delta_{\mathrm{C}} 172.2(\mathrm{C}-2 "-$ $\left.\mathrm{OCOCH}_{3}\right)$, and $\delta_{\mathrm{H}} 4.76(\mathrm{H}-4 ") / \delta_{\mathrm{C}} 172.9\left(\mathrm{C}-4^{\prime \prime}-\mathrm{OCOCH}_{3}\right)$ (Figure 2). Therefore. the stnicture of 1 was established to be meansetin 3-(2".4"-diacetylrhamnoside).

The antioxidant activity of 1 was evaluated by free radical scavenging activity against DPPH radical. The $\mathrm{IC}_{50}$ of 1 . defined as the necessary concentration at which the DPPH radical generated by the reaction sy'stems was scavenged by $50 \%$, was $14.5 \mu \mathrm{M}$.

The known compounds were identified by comparing their spectral data with reported in the literatures. Furthermore. compounds +-10 were isolated from the genus of Myrsine for the first time

\section{Experimental}

General Procedures. Optical rotation was measured with Perkin-Elmer-34l polarimeter. IR was obtained on a NicoletMagna-750-FTR spectrometer $\mathrm{KBr}$ pellets in $\mathrm{cm}^{-1}$. UV was determined on a Varian CARY 300 Bio spectrometer t.max in $\operatorname{nm}(\log \varepsilon) .{ }^{1} \mathrm{H}-\mathrm{NMR}(400 \mathrm{MHz})$ and ${ }^{13} \mathrm{C}-\mathrm{NMR}(100 \mathrm{MHz})$ was run on a Bnuker-DRX-400 spectrometer. ESI- and HR-
ESI-MS were recorded on LCQ-Deca and Q-Tof Ultima mass spectrometers, respectively.

Plant Material. The stems of 1 . africana $\mathrm{L}$. were collected in March 2005 from Dali of Yunnan Province. P. R. China. and was authenticated by Dr. Ji Huang of Shanghai Institute of Materia Medica. Chinese Academy of Sciences. A voucher specimen (No. 20050308) was deposited at the Herbarium of Shanghai Institute of Materia Medica.

Extraction and Isolation. The dried and powdered stems of M. africana L. $(6 \mathrm{~kg})$ were extracted with $95 \%$ ethanol $(50 \mathrm{~L}$. $2 \mathrm{~d} \times$ 3) by maceration. The solvent was evaporated under reduced pressure. and the residue $(650 \mathrm{~g})$ was suspended in $\mathrm{H}_{2} \mathrm{O}$ and then partitioned successively with petroleum ether, $\mathrm{CHCl}_{2}$. EtOAc and $n-\mathrm{BuOH}$. The EtOAC-soluble part $(55 \mathrm{~g})$ was subjected to column chromatography over silica gel (2 $\mathrm{kg}$ ). eluting with the mixture of chloroform and methanol in an order of increasing polarity to give 7 fractions (Fr.l-Fr.7). Fr.4 was further cluromatographed over silica gel colunm and ODS columns to afford compounds 1 (42 $\mathrm{mg}$ ). 5 (190 mg). and $7(10 \mathrm{mg})$. Fr. 5 was separated over silica gel column eluting with chloroform-methanol $(8: 1 \mathrm{v} / \mathrm{v})$ to give 5 subfractions (Frs.5.A -5.E). Fr.5.A was further purified over ODS-A gel and Sephadex LH-20 columns to afford compound 6 (58 $\mathrm{mg}$ ). By using the same procedure. $2(127 \mathrm{mg})$ and $8(21 \mathrm{mg})$ were isolated from Fr.5.B and Fr.5.C. respectively. Re-chromatography of Fr.6 over silica gel coulmn with eluant of chloroform-methanol $(8: 1 \mathrm{v} / \mathrm{v}$ ) yielded 5 subfractions (Frs.6.A-6.E). Fr.6.B and Fr.6.E. were further chromatographed over ODS-A gel and Sephadex LH-20 colunnus to give 9 (363 mg). and $3(390 \mathrm{mg}$ ). respectively. The $n-\mathrm{BuOH}$-soluble part $(155 \mathrm{~g}$ ) was subjected to column chromatography (macroporous resin (i.d. $10 \times 80 \mathrm{~cm}$ ). $\left.\mathrm{EtOH} / \mathrm{H}_{2} \mathrm{O}(\mathrm{v} / \mathrm{v}) 0: 100.10: 90,30: 70,50: 50.70: 30.95: 5\right)$ : Frs.A-F. FrC ( $30 \%$ EtOH, $30 \mathrm{~g})$ was separated by column chromatography $\left(\mathrm{SiO}_{2}, \mathrm{CHCl}_{3} / \mathrm{MeOH} 100: 0 \rightarrow 0: 100\right)$ to give 8 fractions (Frs. C. I-C.8). Fr.C.5 was repeatedly chromatographed over silica gel. Sephadex LH-20. and ODS gel columns to give 4 ( $43 \mathrm{mg}), 10$ (38 $\mathrm{mg}$ ). 
Compound 1: Yellow amorphous powders. $[\alpha]_{\mathrm{L}}^{\frac{7 n}{7}}-189.7$ ( $\mathrm{C}$ $=0.310 . \mathrm{MeOH}): \mathrm{UV} \lambda_{\text {max }}(\mathrm{MeOH}): 221(\log \varepsilon 4.79) .268(\log$ $\varepsilon$ 4.12). $332(\log \varepsilon 4.35)$. IR ( $\mathrm{KBr}) v_{\text {тах }} 3411.2941 .1731$. 1612. 1442. $1371 \mathrm{~cm}^{-1}$; ESI-MS $m / z: 333$ [M+H-188]'. 563 $\left[\mathrm{M}+\mathrm{H}^{-}, 1147[2 \mathrm{M}+\mathrm{Na}]^{+}, 56 \mathrm{I}[\mathrm{M}-\mathrm{H}]^{-}, 1123[2 \mathrm{M}-\mathrm{H}]^{-}\right.$. HR-ESIMS: $m / z 585.1191\left[\mathrm{M}+\mathrm{Na}^{-}\right.$(calcd. 585.1220 for $\mathrm{C}_{26} \mathrm{H}_{26} \mathrm{O}_{14}$ $\left.\mathrm{Na}^{-}\right) .{ }^{1} \mathrm{H}$ - and ${ }^{13} \mathrm{C}$-NMR data see Table 1.

Acid Hydrolysis of 1 . Acid hydrolysis of 1 and sugar identification was conducted according to a standard procedure. In brief. 1 (ca. $2.0 \mathrm{mg})$ in $2 \mathrm{~N} \mathrm{HCl} /$ dioxane $(1: 1 \mathrm{v} / \mathrm{v}: 2 \mathrm{~mL})$ was refluxed for $2 \mathrm{~h}$. On cooling, the mixture was neutralized with $\mathrm{NaHCO}_{3}$. After extraction with AcOEt. the aq. layer was concentrated by blowing with $\mathrm{N}_{2}$. The residue was purified by $\mathrm{CC}$ (Sephadex $\mathrm{LH}-20: \mathrm{MeOH} / \mathrm{H}_{-} \mathrm{O}$ l:L v/v) to give the sugar mixture. The purified sugar and standard L-rhamnose (Sigma. USA) were treated with 1-cysteine methyl ester hydrochloride ( $2 \mathrm{mg}$ ) in pyridine $\left(1 \mathrm{~mL}\right.$ ) at $60^{\circ} \mathrm{C}$ for $1 \mathrm{~h}$. Then, the soln. was treated with $\mathrm{N}, \mathrm{O}$-bis(trimethy lsilyl)trifluoroacetamide $(0.02$ $\mathrm{mL}$ ) at $60^{\circ} \mathrm{C}$ for $\mathrm{l}$ h. The supernatant was applied to GLC analy sis (Supelco: $230^{\circ} \mathrm{C}, \mathrm{N}_{2}$ ). L-rhamnose ( $\mathrm{t}_{\mathrm{R}} 16.7 \mathrm{~min}$ ) was detected from 1 by comparing its retention time with that of the authentic sample.

DPPH Radical Scavenging Assay. The DPPH radical scavenging assay was performed as reported previously with slight modification. ${ }^{16}$ In brief. $20 \mu \mathrm{L}$ of the new compound at final concentrations of $6.25 \mu \mathrm{M}$ to $200 \mu \mathrm{M}$ was added to $180 \mu \mathrm{L}$ of a $150 \mu \mathrm{M} \mathrm{MeOH}$ solution of DPPH in a well of 96-well plate. The absorbance of reaction misture was measured after 30 min of incubation at room temperature in dark using a microplate reader (TECAN Austria Gmbh. Austria). Controls containing methanol instead of the antioxidant solution and blanks containing methanol instead of DPPH solution were also made. The scavenging activity of the DPPH radical by the samples was calculated according to the following equation: DPPH scavenging activity $(\%)=(1 \cdot($ Abs. of sample-Abs. of blank $) /$
Abs. of control) $\times 100$. The percentage of scavenging activity was plotted against the sample concentration to obtain the IC 5 (I.

\section{Refeiences}

1. State Administration of Traditional Chinese Medicine of the People s Republic of China. Zhong Hua Ben Cao, Shanghai Sci \& Tech Press: Shanghai, 1985; Vol. 3, p 245.

2. Arot Manguro, L. O.; Midiwo, J. O.; Kraus, W. Phytochentistry 1996. $\$ 3.1107$.

3. Arot Manguro, L. O.; Midiwo, J. O.; Kraus, W. Nat. Prod. Sci. 1997, 3,8 .

4. Arot Manguro, L. O.; Midiwo, J. O.; Kralls, W. Kat. Prod Lett. $1996,9,121$

5. Arot Manguro, L. O.; Midiwo, I. O.; Kraus. W.; Ugi, I. Phntochemismy 2003, 64, 855 .

6. Li, X. H.; McLaughlin, J. L. J. Nat. Prod. $1989,52,660$.

7. Arot Mangulro, L. O.; Midiwo, J. O.: Kralls, W. Planta Med. $1997,63,290$

8. Fossen, T.: Lársen, A.: Kiremire, B. T:; Andersen, O. M. Phochemistry 1999, 51, 1133

9. Mahmoud, II, Marzouk, M. S. A.; Moharram, F. A.; El-Gindi, M. R.; Hàssan, A. M. K. Plntochemistiv 2001, 58, 1239.

10. Timbola, A. K.; Szpoganicz, B.; Branco, A.; Monache, F. D.; Pizzolatti, M. G. Fitoterapia. 2002, 73, 174

11. Balde, A. M.; Pieters, L. A.; Gergely, A.; Kolodziej, H.; Claeys, M: Vlietinck, A. J. Ptwochemistry 1991, 30, 337.

12. Chen, Y.; Yang, G. Z.: Li, Y. C. Kat. Prod. Res. Dev 2005, 17, 301

13. Miyaichi, Y.: Nunomura, N.: Kawata, Y,; Kizl, H.: Tomimori, T.: Watanabe, T.: Takano, A.: Malla, K. J. Chem. Pham. Bull. 2006, 5t, 136.

14. Ogawa, K.; Kawasaki, A.: Omura, M.: Yoshida, T.: Ikoma, Y.; Yano, M. Plytochemistry 2001, $57,737$.

15. Sakushima, A.: Coskun, M.: Hisada, S.; Nishibe, S. Phutochemism $1983,22,1677$.

16. Moon, S. S.; Rahman, M. A. Bull. Korean Chem. Soc. 2007, 28 , 827 